\title{
Effectiveness of selection, parent-offspring correlation and regression in bacterial blight resistance genes introgressed rice segregating population
}

\author{
Ponnaiah Govintharaj $^{{ }^{*}}$ Shalini Tannidi ${ }^{1}$ \\ Manonmani Swaminathan ${ }^{1}$ Robin Sabariappan ${ }^{1}$
}

'Department of Rice, Centre for Plant Breeding and Genetics, Tamil Nadu Agricultural University, Coimbatore, 641003, Tamil Nadu, India. E-mail:govinth.tnau@gmail.com. *Corresponding author.

\begin{abstract}
The effectiveness of early generation selection was practiced in bacterial blight resistance genes introgressed $F_{2}$ and $F_{2: 3}$ population of the cross $C B 174 R \times I R B B 60$ in rice. $F_{2}$ Selection have been proved to be robust and effective tool in crop improvement program. Selection differential was positive for all studied traits. Selection response was high for number of grains, thus indicating the effectiveness of selection for these character. Realized heritability was found high for number of grains and thousand grain weight, suggested that direct selection was effective. Expected selection response and predicted genetic gain was high for number of grains. Parent-offspring correlation showed low but significance association for number of productive tillers $\left(r=0.47^{* *}, P<0.01\right)$, single plant yield $\left(r=0.35^{* *}, P<0.01\right)$ and $\left(r=0.30^{*}, P<0.05\right)$ panicle length in $F_{2}$ and $F_{2: 3}$ generation indicates that selection was fruitful in early generation. Statistically regression coefficient was not significant linear dependence of the mean of $F_{2}$ and $F_{2: 3}$ generation.

Key words: selection response, realized heritability, selection differential.
\end{abstract}

Efetividade da seleção, correlação pais-prole e regressão nos genes de resistência à ferrugem bacteriana introgressaram a população segregante de arroz

RESUMO: A eficácia da selecção das primeiras gerações foi praticada na população F2 e F2: 3 de CB $174 R \times I R B B 60$ do gene bacteriano. A seleção foi positiva para todos os caracteres estudados. A resposta de seleção foi alta para o número de grãos. A herdabilidade realizada foi encontrada alta para o número de grãos e mil grãos de peso, sugeriu que a seleção direta foi eficaz. A resposta à seleção esperada e o ganho genético previsto foi elevado para o número de grãos. A correlação entre pais e filhos mostrou forte associação com o número de latifundiários produtivos $\left(r=0,47^{* *}, P<0,01\right)$, produção única de planta $\left(r=0,35^{* *}, P<0,01\right)$ e $\left(r=0,30^{*}, P<0,05\right)$ Comprimento em $F 2$ e $F$. geração indica que a seleção foi frutífera. O coeficiente de regressão estatística não foi dependência linear significativa da média de $F 2$ e $F_{2: 3}$ geração. Palavras-chave: seleção, ardor bacteriano, correlação, regressão.

\section{INTRODUCTION}

Rice (Oryza sativa L.) is a major food crop in India and the estimated total rice production was 103.61 million tones during 2015-16, which was 1.87 million tones lower as compared to the year 201415 production (105.48 million tones) (Agricultural situation in India, 2016). Bacterial blight (BB) is caused by Xanthomonas oryzae pv. oryzae (Xoo) and could be identified by two symptoms on rice; kresek and leaf blight. Kresek is the more destructive manifestation of the disease. Leaves of entire plants turn pale yellow and wilt during the seedling to early tillering stages. Leaf blight is the more common disease, in which the lesions on the leaf blades may extend to the leaf sheath. Lesion enlarges in length and width, and may have wavy margins. BB disease of rice, in terms of yield losses across the globe (DAS et al., 2014) and yield losses up to $80 \%$ depending on the stage of the crop, cultivar susceptibility, and environmental conditions (SRINIVASAN \& GNANAMANICKAM, 2005). For increasing the yield potential, hybrids are considered as an important strategy in any crop. Even though, hybrids are performing well for yield and 
quality, but susceptible to biotic stress like bacterial blight which reduces yield. Gene pyramiding is a very useful approach to maximize utilization of existing gene resources. Pyramiding multiple resistance genes into an existing variety proves to be an effective approach for achieving broad-spectrum and durable resistance in rice (CHEN et al., 2009). Incorporation of resistance genes into both parents of hybrid is necessary for expression of desired level of resistance. Among the segregating populations $\mathrm{F}_{2}$ generation is most crucial, where selection has to be done more critically. Segregating populations would allow the gene expression for particular traits. Effectiveness of early generation selection was studied by many researchers in wheat through correlations between $\mathrm{F}_{2}$ and $F_{3}$ (PAWAR et al., 1989) and between $F_{2}$ and $F_{3}$ and $\mathrm{F}_{3}$ and $\mathrm{F}_{4}$ (SAINI \& GAUTAM, 1990). Estimates of realized heritability of the particular trait is important in determining its response to yield and its components has been reported by some workers in rice (KATO, 1997; TAKEDA \& SAITO, 1983; GRAVOIS \& MCNEW, 1993). Selection pressure in rice based on grain yield, total tillers and grain per panicle could be advantageous (TALWAR, 1976). Effectiveness of early generation selection could be reduced by genotype and environment interaction (WHAN et al., 1981; RAHMAN \& BAHL, 1986). Direct selection may not be effective in segregating population for improvement of grain yield (BARTLEY \& WEBER, 1952; JOHNSON et al., 1955). Parent offspring correlation and regression between two generations shows lesser influence of environment and it's very useful method for selection in segregating population. Therefore, present study aimed to know agronomical performances of the bacterial blight resistance genes introgressed individuals with subsequent generations and thus will help to improve breeding efficiency.

\section{MATERIALS AND METHODS}

\section{Plant materials}

The experimental materials were consisted of $F_{2}$ population obtained from $F_{1}$ cross of $C B 174$ $\mathrm{R} \times \mathrm{IRBB} 60 . \mathrm{CB} 174 \mathrm{R}$ is the restorer parental line of released rice hybrid CORH 4 (COMS 23A/CB $174 \mathrm{R}$ ) in TNAU, having the features of medium slender grain type and matures in 135 days. IRBB 60 is a donor parent for bacterial blight resistant, carrying the genes of Xa21, xa13 and xa5 on chromosome 11, 8 and 5, respectively. An experiment was conducted at Department of Rice, Tamil Nadu Agricultural University, Coimbatore. Three/two genes introgressed $\mathrm{F}_{2}$ individuals were identified and advanced to obtain $\mathrm{F}_{2: 3}$ population based on gene specific SSRs genotyping. Finally, fifty four plants were selected and selfed to make $\mathrm{F}_{2: 3}$ families and nine plants from each $\mathrm{F}_{2: 3}$ families were evaluated. The standard agronomical practices were followed through the season to grow healthy crop.

\section{Traits measured}

Data was collected on individual plants in $\mathrm{F}_{2}$ and nine plants were in each $\mathrm{F}_{2: 3}$ families at or after physiological maturity on the basis of single plant. Traits were included plant height $(\mathrm{cm}$, from the ground level to the tip of the primary panicle of selected plants at the time of maturity), number of productive tillers (panicle bearing tillers counted), panicle length $(\mathrm{cm}$, length of the panicle on the main axis measured at the grain maturity stage), number of grains (dry threshed grain per plant used to count by seed counter), thousand grain weight (g, weight of the dry threshed 1000 grain per plant) and single plant yield ( $g$, weight of the dry threshed grain per plant).

\section{Data analysis}

Experimental data on aforesaid traits were subjected to selection differential and response to selection were worked out as suggested by SINGH \& SINGH, (1994), while realized heritability was estimated as per FALCONER \& MACKAY, (1996). The expected response to selection expressed as $\%$ of the base population mean ( $\%$ RS) and the expected genetic gain (PGG) were calculated using the formulas reported by CRUZ et al. (2012). Parentoffspring regression was calculated using GraphPad Prism 5.0 (GraphPad Software, Inc., San Diego, CA), early generation evaluation was also done by parentoffspring correlation between $\mathrm{F}_{2}$ selections and with their progenies in $\mathrm{F}_{2: 3}$ using Microsoft excel 2007 (Microsoft Crop., Redmond, WA, USA).

\section{RESULTS AND DISCUSSION}

Based on individual plant performances for disease resistance, yield and five other traits 
which were component of yield performance of $54 \mathrm{~F}_{2}$ plants were selected and evaluated in $\mathrm{F}_{2: 3}$ generation. Heritability mainly studied to determine how much variation in the phenotype in a population is due to genetic variation between individuals in that population. To develop superior cultivar, there should be high mean values with adequate genetic variability it could be achieved in segregating populations like $\mathrm{F}_{2}$ and $\mathrm{F}_{3}$ Higher estimate of realized heritability was reported in number of grains and thousand grain weight, which indicated that selection was effective in $F_{2}$ population. Similar findings were also reported that selection for heritable characters like thousand grain weight was effective in early generation in rice (SUN, 1979; SUBRAHMANYAM et al., 1986; SUREK \& BESER, 2005; KUMAR et al., 2009). Relatively low realized heritabilities were observed in plant height, panicle length, number of productive tillers and single plant yield in $\mathrm{F}_{2}$ generation. Of these traits, plant height (TORIYAMA \& FUTSUHARA, 1958; YAMAMOTO \& TORIYAMA, 1971) and panicle length showed lower heritability compared with other traits. Most of the studied characters in $\mathrm{F}_{2}$ generation showed negative direction in selection response and realized heritability. Although, observed realized responses for these two traits in this cross which might be explained by genotypic differences between their parents and were utilized in breeding programme. Similar results were previously reported by MISHRA et al. (1993). The present study showed that selection differential was positive value for the studied traits except for thousand grain weight in $\mathrm{F}_{2}$. This finding was concluded that genetic drift and inbreeding was low in $\mathrm{F}_{2}$ population (FALCONER \& MACKAY, 1996). Highest and positive realized heritability was reported between $\mathrm{F}_{2}$ generation for number of grains (KATO, 1997). Single plant yield $\left(\mathrm{r}=0.35^{* *}\right.$, $\mathrm{P}<0.01)$ exhibited positively significant correlation coefficients between $\mathrm{F}_{2}$ and $\mathrm{F}_{2 \cdot 3}$, indicating that strong associations between this trait. Similar kinds of results were reported by DHANRAJ et al. (1987), JANGALE et al. (1987), KUMAR et al. (2009), BARMAN \& BORAH (2012) for grain yield. Some of researchers emphasized the use of early testing in $\mathrm{F}_{2}$ and subsequent generations for yield (SNEEP, 1977; COOPER, 1981). SHEBESHKI (1967) suggested that for the identification of superior gene combinations even in the heterozygote, certainly some point of view the proportion of the plants with most desirable gene combination decreases rapidly with the advancement of generations and if these were not selected in the early generations even if heterozygote condition, these would be lost. The present results get supported with the suggestion of SHEBESHKI (1967) as higher number of superior alleles governed individuals were recovered when early selection in $F_{2}$ was practiced. Statistically regression coefficient was not significant linear dependence of the mean of $\mathrm{F}_{2}$ and $\mathrm{F}_{2}:_{3}$ generation (Table 1 and 2, Figure 1). This finding might be the reason of accumulating two or three genes introgressed $\mathrm{F}_{2}$ and $\mathrm{F}_{2: 3}$ individuals were used (either homozygous or heterozygous state) and it will segregate in $\mathrm{F}_{2: 3}$ families and, it should need to be studied further.

Table 1 - Estimates of selection parameters in $\mathrm{F}_{2}$ and $\mathrm{F}_{2: 3}$ progenies for yield and its component traits in the cross $\mathrm{CB} 174 \mathrm{R} \times \mathrm{IRBB} 60$.

\begin{tabular}{|c|c|c|c|c|c|c|}
\hline Parameters & PH & NPT & PL & NG & $1000 \mathrm{GW}$ & SPY \\
\hline \multicolumn{7}{|c|}{ - Based on $F_{2}$ selections---1 } \\
\hline $\mathrm{F}_{3}$ mean & 113.56 & 12.56 & 26.04 & 158.11 & 19.10 & 25.18 \\
\hline Selection Response & -0.08 & -0.98 & -0.03 & 1.12 & -2.29 & -2.85 \\
\hline Selection Differential & 13.12 & 2.02 & 3.27 & 39.38 & -1.94 & 2.06 \\
\hline Realized Heritability & -164.00 & -2.06 & -109.00 & 35.16 & 0.85 & -0.72 \\
\hline RS (\%) & -0.08 & -9.30 & -0.13 & 0.94 & -10.88 & -12.33 \\
\hline PGG & 100.36 & 9.56 & 22.74 & 119.85 & 18.75 & 20.27 \\
\hline
\end{tabular}

Note: PH: Plant height $(\mathrm{cm})$, NPT: Number of productive tillers, PL: Panicle length $\quad(\mathrm{cm})$, NG: Number of grains per panicle, $1000 \mathrm{GW}$ : Thousand grain weight (g), SPY: Single plant yield (g). 
Table 2 - Parent-offspring correlation for yield and their component traits in rice cross of CB $174 \mathrm{R} \times$ IRBB 60 .

\begin{tabular}{lcc}
\hline Traits measured & Correlation coefficient & Regression coefficient \\
& F2_F3 & F2_F3 \\
Plant height & $0.13^{\mathrm{ns}}$ & $0.02^{\mathrm{ns}}$ \\
\hline Number of productive tillers & $0.47^{* *}$ & $0.22^{\mathrm{ns}}$ \\
Panicle length & $0.30^{*}$ & $0.09^{\mathrm{ns}}$ \\
Number of grains & 0.00 & 0.00 \\
Thousand grain weight & $0.05^{\mathrm{ns}}$ & 0.00 \\
\hline Single plant yield & $0.35^{* *}$ & $0.12^{\mathrm{ns}}$ \\
\hline
\end{tabular}

*** significant at $\mathrm{P}<0.05$ and $\mathrm{P}<0.01$, respectively. Note: $\mathrm{PH}$ : Plant height $(\mathrm{cm}), \mathrm{NPT}$ : Number of productive tillers, PL: Panicle length (cm), NG: Number of grains per panicle, $1000 \mathrm{GW}$ : Thousand grain weight (g), SPY: Single plant yield (g).

\section{CONCLUSION}

Present study confirmed that thus usefulness of selection in early generation and it may have greater impact on breeding program of rice with respect to thousand grain weight and single plant yield. Parent-offspring correlation showed strong association for number of productive tillers, single plant yield and panicle length in $\mathrm{F}_{2}$ and $\mathrm{F}_{2 \cdot 3}$ generation indicates that selection was effective at this stage.

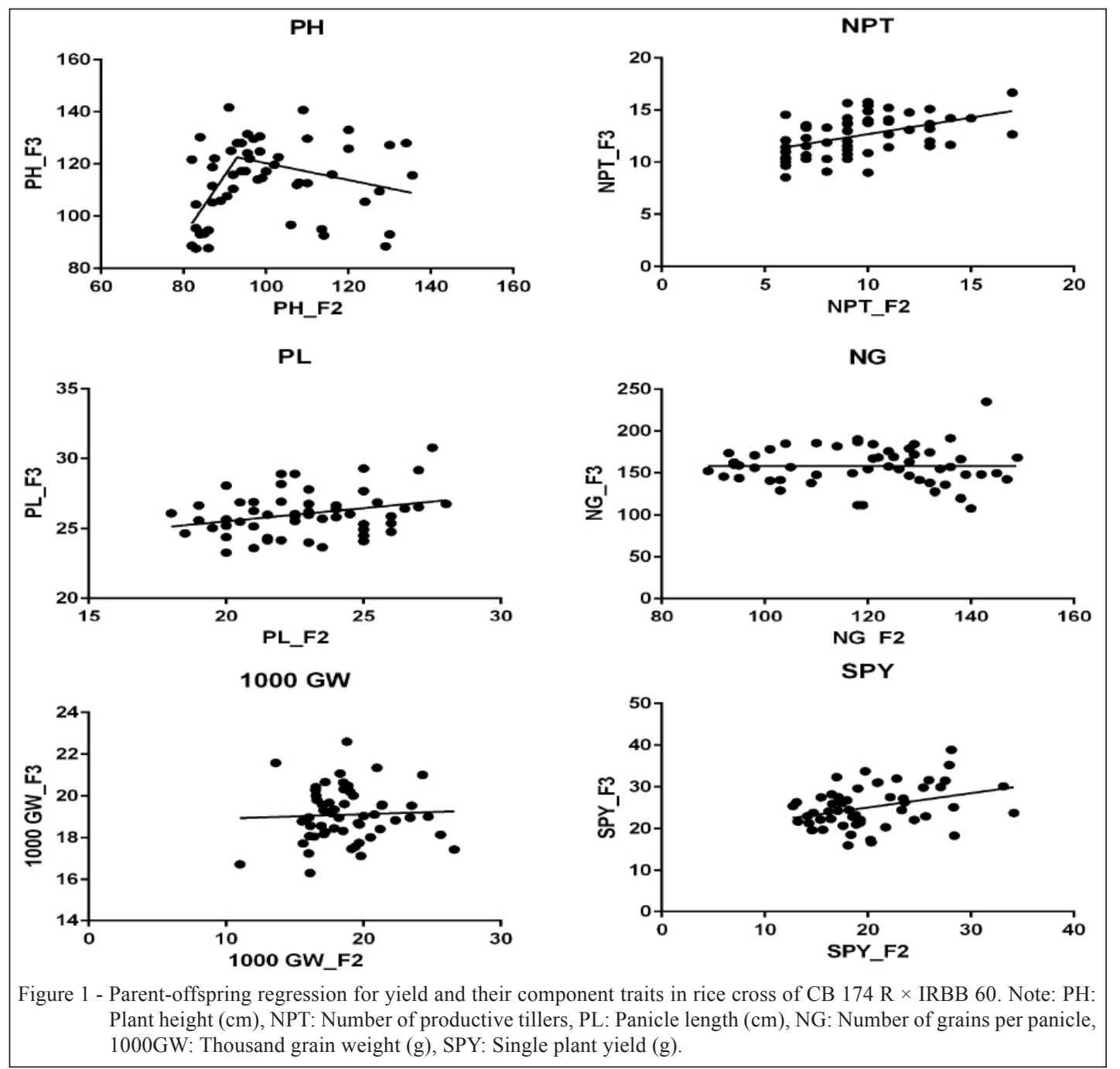

Ciência Rural, v.47, n.9, 2017. 


\section{REFERENCES}

AGRICULTURAL Situations in India, 2016. Available from: $<$ http://eands.dacnet.nic.in/PDF/March2016.pdf >. Accessed: Feb. $28,2017$.

BARMAN, D; BORAH, S.P. Effect of selection response on $\mathrm{F}_{3}$ and $\mathrm{F}_{4}$ generation for yield and yield component characters in mutant rice strain (Oryza sativa L.). APCBEE Procedia, v.4, p.183-187, 2012. Available from: <http://www.sciencedirect.com/science/ article/pii/S2212670812002011>. Accessed: Sept. 12, 2015.

BARTLEY, B.G; WEBER, C.R. Heritable and non heritable relationship and variability of agronomic characters in sucessive generations of soybean crosses. Agronomy Journal, v.44, no.9, p.487-493, 1952. Available from: <https://dl.sciencesocieties.org/ publications/aj/abstracts/44/9/AJ0440090487? access $=0 \&$ view $=p$ df>. Accessed: Apr. 29, 2016.

CHEN, J.M. et al. Breeding hybrid rice restoring line with double resistance to rice blast and bacterial blight by marker-assisted selection. Molecular Plant Breeding, v.7, n.3, p.465-470, 2009

COOPER, R.L. Development of short statured soybean cultivars. Crop Science, v.21, n.1, p.127-131, 1981. Available from: $<$ https:// dl.sciencesocieties.org/publications/cs/abstracts/21/1/CS0210010 127? access $=0 \& v i e w=p d f>$. Accessed: May 27, 2016.

CRUZ, C.D. et al. Modelos biométricos aplicados ao melhoramento genético. 4.ed. Viçosa: UFV, 2012. ISBN 141 9788572694339 .

DAS, B. et al. Genetic diversity of the conserved motifs of six bacterial leaf blight resistance genes in a set of rice landraces. BMC Genetics, v.15, p.82, 2014. Available from: $<$ http://bmcgenet. biomedcentral.com/articles/10.1186/1471-2156-15-82>. Accessed: Feb. 19, 2017.

DHANRAJ, A. et al. Studies on character association in the $\mathrm{F}_{2}$ generation of ten selected crosses in rice (Oryza sativa L.). Journal of Research, v.15, n.1, p.64-65, 1987.

FALCONER, D.S.; MACKAY, T.F.C. Introduction to quantitative genetics. 4.ed. London: Longman, 1996. 464 p.

GRAVOIS, K.A.; MCNEW, R.M. Genetic relationship among and selection for rice yield and yield components. Crop Science, v.33, n.2, p.249-252, 1993. Available from: <https://dl.sciencesocieties. org/publications/cs/abstracts/33/2/CS0330020249? access $=0 \&$ vie $\mathrm{w}=\mathrm{pdf}>$. Accessed: May 28, 2016.

JANGALE, R.D. et al. Association of grain yield with other characters in segregating generation of upland paddy. Journal of Maharashtra Agricultural Universities, v.12, p.47-48, 1987.

JOHNSON, H.W. et al. Genotypic and phenotypic correlations in soybean and their implication in selection. Agronomy Journal, v.47, n.10, p.477-483, 1955. Available from: <https:// dl.sciencesocieties.org/publications/aj/abstracts/47/10/ AJ0470100477/preview>. Accessed: June 03, 2015.

KATO, T. Selection response for the characters related to yield sink capacity of rice. Crop Science, v.37, n.5, p.1472-1475, 1997. Available from: <https://dl.sciencesocieties.org/publications/cs/ abstracts $/ 37 / 5 / \mathrm{CS} 0370051472$ ? access $=0 \&$ view $=$ pdf $>$. Accessed June 18, 2016
KUMAR, M. et al. Effectiveness of $\mathrm{F}_{2}$ and $\mathrm{F}_{3}$ plant selection for yield and its components in rice. Oryza, v.46, n.1, p.1720, 2009. Available from: <http://www.indianjournals.com/ ijor.aspx target $=$ ijor: oryza $\&$ volume $=46 \&$ issue $=1 \&$ type $=$ toc $>$. Accessed: Mar. 04, 2015.

MISHRA, S.K. et al. Selection model in rice (Oryza sativa L.). Indian Journal of Genetics and Plant Breeding, v.53, n.2, p.131137, 1993. Available from: <http://www.indianjournals.com/ijor. aspx?target $=$ ijor:ijgpb\& volume $=53 \&$ issue $=2 \&$ article $=0 \quad 05>$. Accessed: Aug. 26, 2016

PAWAR, I.S. et al. A study of intergeneration correlation in four wheat crosses. Haryana Agricultural University Journal of Research, v.19, p.76-78, 1989.

RAHMAN, M.A.; BAHL, P.N. Evaluation of early generation testing in chickpea. Plant breeding, v.97, n.1, p.82-85, 1986. Available from: <http://onlinelibrary.wiley.com/ doi/10.1111/j.1439-0523.1986.tb01306.x/abstract>. Accessed: June 13, 2016.

SAINI, D.P.; GAUTAM, P.L. Early generation selection in durum wheat. Indian Journal of Genetics, v.50, n.2, p.147-152, 1990.

SHEBESHKI, L.H. Wheat breeding. In: CANADIAN CENTENNIAL WHEAT SYMPOSIUM, 1967, Saskatchewan, Canada. Proceedings... Saskatoon, Saskatchewan, Canada: Modern Press, 1967. p.253.

SINGH, R.K.; SINGH, P.K. A manual on genetics and plant breeding: experimental technique. New Delhi, India: Kalyani Publishers, 1994. 326 p.

SNEEP, J. Selection for yield in early generations of self fertilizing crops. Euphytica, v.26, n.1, p.27-30, 1977. Available from: <http://link.springer.com/article/10.1007/BF00032064>. Accessed: Nov. 13, 2016.

SRINIVASAN, B.; GNANAMANICKAM, S. Identification of a new source of resistance in wild rice, Oryza rufipogon to bacterial blight of rice caused by Indian strains of Xanthomonas oryzae pv. oryzae. Current Science, v.88, p.1229-1231, 2005. Available from: <http://www.currentscience.ac.in/Downloads/ download pdf.php?titleid=id_088_08_1229_1231_0> Accessed: Feb. 02, 2017

SUBRAHMANYAM, D. et al. Heritability of yield and other traits and inter-relationships among traits in $F_{2}$ to $\mathrm{F}_{5}$ generation of three crosses of rice. Indian Journal of Genetics and Plant Breeding, v.46, n.2, p.390-393, 1986. Available from: <http://www.indianjournals.com/ijor.asp $\mathrm{x}$ ? target $=$ ijor $:$ ijgpb \& volume $=46 \&$ issue $=2 \&$ article $=0 \quad 17>$. Accessed: Aug. 03, 2016.

SUN, X.C. Estimates of heritability for some major economic characters in hybrid generation of Indica rice. Scientia Agricluturae Sinica, v.4, p.45-50, 1979.

SUREK, H.; BESER, N. Selection for grain yield and its components in early generation in rice (Oryza sativa L.). Trakia University Journal of Science, v.6, n.1, p.51-58, 2005.

TAKEDA, K.; SAITO, K. Heritability and genetic correlation of kernel weight and white belly frequency in rice. Japanese Journal of Breeding, v.33, p.468-480, 1983. 
TALWAR, S.N. Selection index for grain yield and its contributing characters in parietal collection of rice. Indian Agriculture Journal, v.20, n.1, p.35-37, 1976.

TORIYAMA, K.; FUTSUHARA, Y. Estimates of heritabilities on individuals and lines in rice. Japanese Journal of Breeding, v.7, p.208-212, 1958.

WHAN, B.R. et al. The relation between wheat lines derived from $\mathrm{F}_{2}, \mathrm{~F}_{3}, \mathrm{~F}_{4}$ and $\mathrm{F}_{5}$ generations for grain yield and harvest index. Euphytica, v.30, p.414-430, 1981. Available from: $<$ https://link.springer.com/article/10.1007/BF00034006>. Accessed: Aug. 18, 2016.

YAMAMOTO, T.; TORIYAMA, K. Comparison of expected and observed genetic gain in rice selection experiments. Japanese Journal of Breeding, v.21, p.155-159, 1971. Available from: $<$ https://www.jstage.jst.go.jp/article/ jsbbs1951/21/3/21_3_155/_article>. Accessed: Aug. $20,2016$. 